\title{
PEDAGÓGUSKÉPZÉSI MODELLEK: A JÖVŐ PEDAGÓGUSAINAK INKLÚZIÓVAL KAPCSOLATOS ATTITÜDJEI, NÉZETEI
}

\section{PETö ILdIKó}

\author{
a Debreceni Egyetem \\ egyetemi adjunktusa \\ peto.ildiko@mailbox.hu
}

\begin{abstract}
Napjainkban a hagyományos iskolákban a sajátos nevelési igényü tanulók inklúziója az egyik legjelentösebb oktatási kérdés, amivel szembe kell néznie mind az oktatáspolitikának, mind pedig az oktatás minden szereplöjének, nemzeti és nemzetközi szinten egyaránt. A szakemberek körében általánosan elfogadott vélemény az, hogy a megfogalmazott elvárások teljesülésének feltétele, hogy a pedagógusképzés intézményei olyan új pedagógusokat képezzenek, akik valóban képesek nevelni és tanitani az ugyanabban a tanteremben tanuló, különbözö szükségletü gyerekeket és fiatalokat. Jelen tanulmány a magyar nyelven még ismeretlen ATIES, IPD és CIES vizsgáló eszközöket szándékozik bemutatni, illetve egy nemzetközi összehasonlitó vizsgálat néhány tapasztalata alapján öt pedagógusképzési programot abból a szempontból megvizsgálva, hogy hol van a helye a fogyatékostani ismereteknek, aminek kapcsán külön figyelmet kap az „,content infusion”, azaz a diffúz modell.
\end{abstract}

A sajátos nevelési igényü ${ }^{1}$ tanulók iskolai inklúziója az egész világon elterjedt tendencia és gyakorlat. Sok országban (például az USA, Anglia, Kanada és Ausztrália) a törvényhozás látványosan előmozdította az oktatás inkluzív gyakorlatát, de sok fejlődő országban is érezhető, tapasztalható a változás. Bár a törvényhozás, a társadalom- és oktatáspolitika fontos és meghatározó, de nem szükségképpen eredményezi azt, hogy a pedagógusok örömmel üdvözöljék az újításokat, így pl. az inkluzív oktatás gondolatát. Több kutató (Avramidis és Norwich, 2002; Forlin, 2001) arra a következtetésre jutott, hogy az inkluzív nevelést célzó reformok sikeres implementációja nagyrészt a pedagógusok akaratától függ. De már azt is tudjuk, hogy azok a tanárok, akik pozitív attitüddel viseltetnek az inklúzióval szemben, sokkal gyorsabban tudnak változtatni és úgy adaptálni, módosítani a munkamódszereiket, hogy az a sokféle tanulási szükségletủ diákokból álló osztály minden tanulója számára elönyös legyen (Bender et al., 1995; Sharma et al., 2006; Subban és Sharma, 2005). Az is nyilvánvaló, hogy a problémahelyzetekhez és a változásokhoz

\footnotetext{
${ }^{1}$ Továbbiakban: SNI (magyarul) vagy SEN (angolul) a szövegkörnyezettől függően
} 
gyorsan alkalmazkodó tanárok hatással vannak az „átlagosnak” mondható diákoknak az SNI-társaikkal kapcsolatos attitüdjére is (Norwicki és Sandieson, 2002).

\section{Bevezető gondolatok}

A pedagógusoknak az SNI-diákok inklúziójával kapcsolatos attitüdjét sok tényező befolyásolja: az osztályfok, a tanulásban és viselkedésben mutatott nehézségek súlyossága, korábbi tapasztalat fogyatékosokkal, korábbi tanítási tapasztalat SNI tanítványokkal, és az, hogy milyen képzésben részesültek a fogyatékosságokkal kapcsolatban.

A különböző vizsgálatok azt mutatják, hogy az alacsonyabb osztályfokon tanuló SNI gyerekek tanárainak általában pozitívabb a hozzáállásuk, mint a magasabb osztályfokon tanuló, idősebb SNI gyerekek tanárainak. Azok a tanárok, akik olyan tanulókkal vannak kapcsolatban, akik enyhe tanulási problémákkal küzdenek, kedvezőbben nyilatkoznak a tanítványaikról, mint azok, akiknek a tanítványai súlyosabb tanulási problémákat mutatnak (Center és Ward, 1987; Forlin, 1995). Azok, akiknek volt már közvetlen kapcsolatuk sérült személlyel akár pedagógusi munkájuk során, akár magánéletükben, szintén pozitívabbnak tủnnek az inkluzív oktatással kapcsolatban mint azok a pedagógusok, akiknek soha nem volt ilyen kapcsolatuk (Hodge és Jansma, 1999).

Ez utóbbi tendenciát több vizsgálattal bizonyították kutatók (Avramidis és Norwich, 2002; Center és Ward, 1987; Hastings és Graham, 1995; Loreman és Earle, 2007; Sharma et al. 2006; Subban és Sharma, 2005). Ezzel szemben Bradshaw és Mundia (Bradshaw és Mundia, 2005) azt tapasztalták, hogy egy sérült családtag nem javítja a tanárjelölteknek az inklúzióval kapcsolatos hozzáállását. Véleményük szerint „lehetséges, hogy a fogyatékosságról alkotott vélemény kevésbé függ az ilyen jellegü családi kapcsolatoktól, sokkal inkább attól, hogy találkozott-e fogyatékos személlyel az iskolában vagy a helyi közösségben, lakókörnyezetében." (Bradshaw és Mundia, 2005. 572. o.). Az eddigi tapasztalatokhoz hozzá kell tenni, hogy az ezzel a területtel kapcsolatos kutatások még olyan korai szakaszban vannak, hogy meszszemenő vagy általánosítható következtetéseket nem vonhatunk le.

Nyilvánvalónak tủnik, hogy azok a pedagógusok, akik a képzésük során szereztek legalább egy kevés ismeretet a fogyatékosságokról, pozitívabban viszonyulnak az inkluzív neveléshez. Kutatók is hajlanak arra a feltételezésre, hogy a pedagógusképzésben nyújtott fogyatékosságokról szóló ismeretek és a pedagógusok pozitív hozzáállása között pozitív korreláció van. Erre a feltételezésre alapozva sok kutató vizsgálta azt, hogy milyen tartalmú, mélységü és terjedelmü ismereteket tartalmaznak e témában a különböző tanárképzési programok, van-e ezeknek bármilyen hatásuk, és ha van, akkor ez a hatás milyen mértékü és hogyan irányítható (Avramidis et al., 2000; Hastings és Oakford, 2003). 
A vizsgálatok alapján általában az fogalmazható meg, hogy a pályakezdő pedagógusok nyitottak arra, hogy olyan enyhe fokban sérült gyerekekkel foglalkozzanak, akik nem igénylik az oktatás-nevelés jelentős módosítását (Avramidis és Norwich, 2002). Árnyaltabb a kép, ha azt vizsgáljuk, hogy a végzés előtt álló tanárjelöltek hogyan éreznek, amikor arra gondolnak, hogy nagy valószínüséggel ők is kerülnek majd olyan helyzetbe, hogy az osztályukban SNI viselkedészavaros gyerekek is tanulni fognak. A végzés elött álló tanárjelöltek erre a lehetséges helyzetre gondolva kevésbé elfogadóak, mint a többi SNI kategóriájával kapcsolatban (Avramidis et al. 2000; Forlin et al. 1996; Sharma et al. 2003; Subban és Sharma, 2005). Viszont az adatok alapján úgy tünik, hogy a már pályán lévő tanárokhoz képest a végzéshez közeli pedagógushallgatók a felsőbb osztályokban tanuló fogyatékos gyerekekröl is pozitívabban gondolkodnak (Hastings és Oakford, 2003). A kutatások alapján az is feltételezhető, hogy a magasabb szintü (MA vagy posztgraduális) képzésben résztvevő hallgatók pozitívabban gondolkodnak az inklúzióról, és kevésbé aggódnak amiatt, hogy SNI-gyerekkel kell foglalkozniuk, mint az alacsonyabb képzési szinten tanulók (például BA-képzésben résztvevők, vagy bármilyen szinten tanulók tanulmányaik megkezdésekor) (Sharma et al. 2006).

A speciális nevelési igényü gyermekekkel kapcsolatos tanárképzésben szerzett ismereteknek tehát van szerepük az SNI-vel kapcsolatos nézetek alakulására. Ezeknek az ismereteknek a közvetítésére az egyik lehetséges módszer a „,content infusion”, ami a fogyatékos emberekre vonatkozó ismereteknek szisztematikus, a képzés minden elemébe való beépítését jelenti a képzés teljes folyamatában (Kowalski, 1995). Sok szerző szerint a ,content infusion”-modell a hagyományos tanegységes forma, azaz az egyszeri hatás helyett éppen a diffúz (,szétszóródó”) jellegével, sajátosságával segíti az inkluzív nevelés elfogadását (Cook, 2002). Kowalskinak (Kowalski, 1995) az a véleménye, hogy azok a pedagógusok, akik a fogyatékosságokkal kapcsolatos ismereteiket hagyományos „szóló” kurzus során szerezték, hamarabb gondolják azt az SNI diákokról, hogy magányosak az iskolában és gyengébb képességüek, mint azok, akik a megfelelő ismereteket több tanegységbe, több témakörbe beépítve szerezték meg. A diffúz modellben a pedagógusjelöltek folyamatosan olyan kihívásokkal találkoznak mind a fogyatékosokkal kapcsolatos ismereteik asszimilálásában, mind pedig ezen tudásuk alkalmazásában, amelynek eredményeképpen emelkedik elkötelezettségi szintjük.

A fentieknek azonban ellentmond egy-két, nem túl régi kutatás, miszerint a diffúz modell nem olyan hatékony, mint azt eleinte feltételezték. Akasmit és Alcorn (1988; In: Sharma et al., 2008) elemezte és értékelte az USA-ban, szövetségi támogatásból kidolgozott és bevezetett „Mainstream Curriculum Infusion Model”-t. Azt találták, hogy a tanárok, akiket diffúz programmal képeztek, úgy érezték, hogy a kapott ismeret, és emiatt a saját tudásuk az együttneveléssel kapcsolatban nem kielégítö. Egy másik tanulmány a diffúz modellel kapcsolatban (Cook, 2002) hasonló eredményeket közölt, vagyis azt találta, hogy a diffúz modellben tanuló pe- 
dagógusjelöltek véleménye és motiváltsága az inklúzióval kapcsolatban jelentősen nem javult.

Sharma és munkatársai (Sharma et al., 2008) egyenesen felvetik a kérdést, hogy a pedagógusképzés jelen formájában megalapozzák-e azt, hogy a tanárok az inklúzió hatásos katalizátorai lehessenek. Ez a kérdés azért fogalmazódhatott meg, mert általában a pedagógusjelöltek legfeljebb csak egy olyan tantárgyat választanak a képzésük ideje alatt, amelyik valamilyen szempontból az inkluzív oktatással foglalkozik. Tehát nem jellemező a diffúz modell. Ezért többen fontosnak tartják, hogy a tanárképzés ideje alatt olyan saját élményeket biztosító „helyzetekbe” kell helyezni a hallgatókat, hogy tanulmányaik befejezésekor ne érezzék kényelmetlenül magukat, ha fogyatékos személlyel találkoznak, sőt, képesek legyenek természetesen kezelni ezeket a szituációkat, és ezzel együtt mutassanak nagyobb hajlandóságot az együttnevelésre.

A pedagógusjelölteknek a korábbi tapasztalataik alapján formálódott véleményén és hozzáállásán túl fontos kérdés az is, milyen tartalom és módszer készít fel őket a legjobban az együttnevelésre. Néhány korábbi kutatásban különböző aspektusokból már vizsgálták, hogy milyen a pedagógushallgatók hozzáállása, mi a véleményük a fogyatékos emberekről, milyen gondokat feltételeznek az inklúzió megvalósításában, és milyen aggályaik vannak az inkluzív oktatással kapcsolatban. (Forlin et al., 2007; Loreman és Earle, 2007; Sharma et al., 2006, 2008). Érdekesség, hogy a vizsgálatok során ugyanazt a kérdőívet használták a különböző országokban. A cél annak kiderítése volt, hogy a pedagógia és más tudományterületek e témára vonatkozó eredményei milyen hatással vannak a pedagógusok attitüdjeire. A vizsgálatok tapasztalatai föleg a pedagógusképzést szervezők számára lehetnek hasznosak.

Sharma, Forlin és Loreman 2008-ban publikálta egy nemzetközi összehasonlító vizsgálat tapasztalatait, amelyet az ATIES, az IPD és a CIES kérdőívekkel végeztek Kanada, Hong Kong és Szingapúr egy-egy, valamint Ausztrália két pedagógusképző intézetében. A kanadai intézményben a diffúz modellt alkalmazták a képzésben, ami azt jelenti, hogy minden tanegységbe beépítették az inkluzív nevelésre vonatkozó ismereteket, nem csak egy (vagy néhány) tantárgy szólt erről. Ezzel szemben a fogyatékosságokat bemutató tanegység Hong Kongban, Szingapúrban és Ausztráliában tíz hetes volt, tehát ezekben a programokban hagyományos, szóló tanegységgel operáltak

A kérdőíves vizsgálatot két időpontban, a képzés első és utolsó szemeszterében végezték el mind az öt intézményben. A fogyatékosságokkal foglalkozó ismeretekre fordított idő a képzések eltérő felépítése miatt természetszerủen eltérő volt. Fontos ezeket a különbségeket kiemelni, mert csak így értelmezhetőek megfelelően a Sharma által vezetett vizsgálat eredményei. De azt sem szabad elfelejteni, hogy bármilyen különbség is mutatkozik a pedagógusok, pedagógushallgatók között az attitüdjükben, kételyeikben, félelmeikben és véleményeikben, az nem tulajdonítha- 
tó pusztán a képzésüknek, hiszen a résztvevőket sokféle más hatás is érte a tanárképzés elött és alatt is.

\section{Ausztrália - hagyományos modell}

Ausztráliában a vizsgálatban résztvevő két intézményben ${ }^{2}$ a hallgatók képzésének kötelező része a speciális oktatásról szóló 20 órás (tíz hetes) tanegység. Az egyik intézmény esetén a tananyag tartalmazza a téma alapfogalmait, a fogyatékosság társadalmi modelljét, a nemzetközi tendenciákat, információkat a többségi iskolában tanuló SNI diákok speciális igényeiről és nevelésük céljairól.

A tantárgy kapcsán a diákok fogyatékos személyekkel is kapcsolatba kerülnek a helyi közösségben, és olyan vendégelöadókat hallgatnak, akik maguk is fogyatékosok, vagy sérült gyerekek szülei, miközben hagyományos nagy előadásokon vesznek részt és kis létszámú szemináriumi csoportokban is dolgoznak. Feladatként ún. hallgatói prezentációra kell felkészülniük a diákoknak, amit egy 25 órás ún. Community Links Programme (CLP) alapján készítenek el a diákok. A CLP lényege, hogy 25 órát kell eltölteniük olyan környezetben (intézményben, szervezetnél), ahol fogyatékosok élnek. Ennek során szabadidős programokban kell részt venniük, szervezniük. A tanegység vizsgával zárul.

A kutatásban részt vett másik ausztrál intézmény önálló tanegységet ajánlott a leendő tanároknak (harmad- vagy negyedéven) gyógypedagógiai témakörben. A tanegység, amely tíz hetes (heti két óra), elsősorban a fogyatékosság szociológiai vonatkozásaira fókuszál. Az első három hét folyamán olyan kérdésekkel foglalkoznak, mint a stigmatizáció, a megfelelő terminológiák, az inkluzív nevelés, az SNI-vel kapcsolatos oktatáspolitika értelmezése, az együttnevelést támogató oktatáspolitika elemzése. A következő hét hét során elsősorban a gyakorlati megvalósításról hallanak a résztvevők: tantervalapú értékelés, képességfejlesztés, kooperatív tanulás, differenciált tanulásszervezés és irányítás. Közben a hatodik héten vendégelőadóként találkoznak a hallgatók egy autista gyermek szülöjével, míg a nyolcadik héten meglátogatnak egy inkluzívan nevelő iskoláskor előtti, korai nevelést folytató intézményt, az utolsó héten pedig sikeres inkluzív tanároktól hallhatnak esettanulmányokat. A félév során a hallgatóknak célzott, képességet fejlesztő kis csoportban is kell dolgozniuk, valamint három feladatot kapnak: prezentáció, újságkészítés és egy vizsgálat. A prezentáció témája segít felismerni az SNI-vel kapcsolatos stratégiákat és az együttnevelés gátjait. Az újságkészítésnek hasonló a témája, mint a prezentációnak, de kiegészül azzal, hogy az újságban mindenki bemutathatja azokat a feladatokat is, amelyeket a kurzus különböző időszakjaiban elvégzett (és amik során a különbözö problémákat feldolgozta és megértette). A vizsgakérdések főleg azok-

\footnotetext{
${ }^{2}$ Faculty of Education, Monash University, Clayton, Victoria, Australia; University of Western Australia
} 
nak az elméleti és gyakorlati kérdéseknek az alkalmazására koncentrálnak, amelyeket a félév során feldolgoztak.

\section{Hong Kong - hagyományos modell}

A Hong Kongban vizsgált pedagógushallgatók a négy éves Bachelor of Education (Secondary), Bachelor of Education (Language) vagy Bachelor of Arts (English Language Teaching ${ }^{3}$ ) képzésre nyertek felvételt, amelynek része egy kötelező tíz hetes (heti két órás) SNI-vel fogalakozó kurzus. A tanegység először a fogyatékosságok orvosi és társadalmi szempontú értelmezésére fókuszál, majd áttekintést ad különböző oktatási stratégiákról, mint például a differenciált óravezetés, tanulótársmodell, kooperatív tanulás. A hallgatók megismerik a különféle pedagógiai irányzatok széles skáláját, miközben előadásokat hallhatnak, kis csoportos beszélgetéseket folytatnak, és problémaalapú tevékenységeket folytatnak. A diákoknak a program során alkalmuk nyílik arra, hogy enyhe fokban sérült diákokat ismerjenek meg a helyi közösségböl, akiknek a szülei és tanárai előadást is tartanak számukra. A kurzus során hallanak továbbá a fogyatékosságok kórtanáról, jellemzőiről, az SNI gyerekek oktatásának céljairól. Feladatuk, hogy tartsanak egy önálló poszterbemutatót, amelynek az elkészítésében egy-egy fogyatékos diák is közremüködik (Forlin és Sin, 2010).

\section{Szingapúr - hagyományos modell}

A szingapúri, az iskoláskor előtti korosztállyal való foglalkozásra készülő pedagógushallgatók képzésének ${ }^{4}$ része egy 30 órás kurzus, nagy létszámú előadás formájában a képzés utolsó szakaszában. A tartalmat négy modulra osztották fel, amelyekben a következőkre összpontosítanak: (1) az iskoláskor elötti korosztály SNI gyerekeivel kapcsolatos eljárások, a diagnózis, nevelésük ökológiája; (2) a gyógypedagógia és az inklúzió, mint nevelési gyakorlat; megbélyegzés, exklúzió; a fogyatékosságok csoportosítása; (3) tantermi gyakorlat, adaptáció és módosítások; speciális sérülésekkel rendelkező emberek jellemzői és nevelési szükségleteik; (4) a speciális fogyatékosságok és a nevelési kérdéseik jellemzői. Az előadások során filmeket mutatnak be sérült kisgyerekekről, megismerkednek a személyes tapasztalatokat megosztó internetes oldalakkal (pl. blogok) és különböző kiadványokkal, valamint a diákoknak látogatást szerveznek egy helyi speciális iskolába.

\footnotetext{
${ }^{3}$ University of Hong Kong, Faculty of Education

${ }^{4}$ Ministry of Education, Singapore
} 
Kanada-diffúz modell

Kanadában az egyik Faculty of Education ${ }^{5}$ képzése a kétéves kiegészitő neveléstudományi BA-képzés (ez After-degree program, posztgraduális), amelyben évfolyamonként 35 hallgató kezdheti el a tanulmányait. Az alacsony keretszám miatt a programba nagy a túljelentkezés, ami lehetővé teszi a jelentkezők megfelelö szempontok szerinti előzetes szelekcióját, a „válogatást”.

A képzési program ugyan az alapfokú (primary) oktatásra való felkészítésre fókuszál, de a megszerzett diplomával a pedagógusok taníthatnak az óvodától a 12. osztályig. A képzési program minden tanegysége kötelező a hallgatóknak, választható tárgyak nincsenek. Ez a kanadai képzés nem kínál kurzusokat kifejezetten az inkluzív oktatás témájában, hanem minden tantárgy érinti ezt a szempontot úgy, hogy bemutatja az együttnevelés filozófiáját és gyakorlatát. Mivel minden tantárgy kötelezö, és a hallgatószám viszonylag alacsony, lehetőség van olyan területeket is megcélozni a különböző kurzusokon keresztül, amelyek segítségével a jelöltek az együttneveléshez szükséges készségeiket, tudásukat és attitüdjeikett fejleszthetik. Nevesített cél a differenciált óravezetés, többféle alternatív értékelés megismertetése a különbözö természettudományos és társadalomtudományos tantárgyak tanításának „módszertanában". A hallgatók a különböző kurzusok során gyakorlati feladatokat kapnak, például egyéni fejlesztési tervet állítanak össze (Individual Programme Plan, IPP), amihez az erre kifejlesztett és az iskolákban kötelezően használt szoftvert használják, valamint esettanulmányt készítenek. Általában elmondható a kétéves programról, hogy társadalmi konstruktivista megközelítésen alapul, ezért a témákat a társakkal és a tanárokkal való beszélgetés, vagy csoportban végzett munka során dolgozzák fel.

\section{Skálák - a képzési formák hatékonysága}

Magától adódnak a kérdések a képzési formák összevetésekor: valóban jelentős-e a különbség a diffúz modell és a hagyományos, önálló tanegység alapú képzés attitüdformáló hatása között? Valóban hatékonyabb-e az ismeretek diffúz, integrált átadása és feldolgoztatása?

Napjainkban kezd kialakulni egy vita, amely azt a kérdést boncolgatja, hogy a pedagógusképzési modellek közül melyik, a diffúz vagy a hagyományos modell teszi alkalmasabbá a leendő tanárokat az inklúzióra. Eddig nagyon kevés kutatás foglalkozott azzal, hogy összehasonlítsa a különbözö képzési szerkezeteket és módszereket, ezért jelenleg még nem áll rendelkezésünkre elég adat ahhoz, hogy eldönthessük, melyik a hatékonyabb forma. A csekély számú kutatás oka az, hogy még nem állnak széles körben rendelkezésünkre olyan eszközök, amelyekkel a kérdéses

\footnotetext{
${ }^{5}$ Faculty of Education, Concordia University College of Alberta, Edmonton, Alberta, Canada
} 
problémákat mérni, tanulmányozni lehetne. Néhány kutatónak köszönhetően azonban már létezik, bár alig ismerten, néhány kérdőív, amelyek segítségével megbízhatóan mérhetőek attitüdök és konkrét vélemények az inklúzió és a fogyatékosság témakörében. Ilyen pl. az ATIES, az IPD és a CIES.

$\mathrm{Az}$ „Attitudes Toward Inclusive Education Scale” (ATIES, Inkluziv Neveléssel Kapcsolatos Attitüdöket Mérö Skála) a pedagógusoknak a hagyományos osztályban tanuló, integrált oktatásban részesülő SNI tanulókkal szembeni pozitív és negatív attitüdjét méri. A hatfokú Likert-típusú attitüdskála 16 olyan állítást tartalmaz, amelyek az inklúzióval kapcsolatos pedagógusi attitüd négy aspektusát vizsgálják: szociális, fizikai, ismeret- és viselkedésbeli. A skála, amelynek kidolgozója Felicia Wilczenski (1992, 2005), alkalmas a különböző, az inklúzióval kapcsolatos helyzetekben jelentkező vélemények és érzések feltárására is (Sharma et al., 2003; Wilczenski, 2005).

Az ATIES kérdöívvel (Sharma et al., 2008) két időpontban (a képzés vagy tanegység elején és végén) végzett vizsgálat eredményei minden országban, kivéve Szingapúrban, különbséget mutatnak. A legnagyobb változás a két ausztrál és a hong kongi intézmény hallgatói körében történt, ahol nagy hangsúlyt helyeznek a fogyatékos gyerekek jellemzöinek és szükségleteinek a megértésére, ami az eredmények szerint képes attitüdbeli változást előidézni.

A kanadai program tartalma sok elemében hasonlít az első ausztrál intézményéhez (A1), például mindkettő sokoldalúan közelít a fogyatékosságokkal és a fogyatékos személyekkel kapcsolatos kérdésekhez, bár az időtartam jelentősen eltér. Azonban a hasonlóság ellenére a diffúz program kisebb attitüdváltozást eredményezett. Ez vajon azt jelenti, hogy az diffúz modell mégsem hatékonyabb, mint a hagyományos tanegység alapú? A kérdésre határozott válasz nem adható, mert fontos minden esetben a minta jellemzőin keresztül értelmezni az adatokat.

Az „Interaction with Persons with a Disability Scale (IPD, Kapcsolat a Fogyatékos Személyekkel Skála), amelyet Gething dolgozott ki 1991-ben, méri a kapcsolatok lehetőségét, érzelmi töltöttségét a fogyatékosokkal kapcsolatban. A hatfokú Likert-típusú, 20 állítást tartalmazó attitüd skálát a szakemberek megbízhatónak nevezik egy 2800 fős vizsgálati csoport eredményei alapján (Forlin et al., 1999). Az IPD skála arra használható, hogy mérje a vizsgálati személyek véleményét a fogyatékosokkal kapcsolatban.

A két ausztrál intézmény válaszadó hallgatóinak körében pozitív változást figyeltek meg a két időpont viszonylatában, míg a kanadai, a hong kongi és a szingapúri résztvevők alig-alig változtak e tekintetben. A különbségeket legjobban az a változó magyarázhatja meg, amelyik a fogyatékkal élő egyénekkel való kapcsolatra vonatkozik. A kanadai hallgatók a képzés során nem kaptak lehetőséget arra, hogy fogyatékos személlyel találkozzanak szervezetten és célzottan, miközben a többi egyetem hallgatói közvetlen tapasztalatokat, saját élményt szerezhettek (Sharma et al., 2008). 
A legtöbb ausztrál, közöttük is elsősorban az első intézményben tanuló diákok hozzáállásában bekövetkező jelentős változás arra hívja fel a figyelmet, hogy nem maga a kapcsolat (meg)léte a meghatározó, hanem a kapcsolat típusa és hossza az, ami fontos, ami valójában a vélemény változását okozza. A képzésben megkövetelték, hogy a hallgatók jelentős időt töltsenek fogyatékos emberekkel közösségi munkájuk során. Így barátságot alakíthattak ki fogyatékos személyekkel, ami véleményük megváltozását hozta magával. Tehát az ausztrál pedagógusképzés ezen formája ugyan nem ad elég ismeretet, de a szisztematikus tervezés biztosítja, hogy a hallgatók olyan tapasztalatokat szerezhessenek, amelyek segítségével megérthetik, hogy egy fogyatékos is lehet barát, akivel jól érezhetik magukat, és e tekintetben nem különböznek másoktól (Sharma et al., 2008).

Ezekre a vizsgálati eredményekre hivatkozva a szakemberek ajánlják (Avramidis és Norwich, 2002; Forlin, 2003) és támogatják a képzés részeként megtervezett és megszervezett kapcsolatteremtési lehetőségeket a pedagógusok pozitív attitüdváltozása érdekében.

A „Concerns about Inclusive Education Scale”-t (CIES, Az Inkluzív Neveléssel Kapcsolatos Aggodalmak Skála) Sharma és Desai (Sharma és Desai, 2002) dolgozta ki a pedagógusok inklúzióval kapcsolatos félelmeinek, aggályainak és kétségeinek a mérésére. A négyfokú Likert-típusú skála 21 állítást tartalmaz.

A CIES használata során összesített pontszámok azt sejtetik, hogy a résztvevők kevésbé vágynak arra, hogy inkluzív osztályban tanítsanak. Különösen magas, az aggodalomra utaló pontszámokat mutattak az ausztrál és a szingapúri hallgatók. Feltételezhető, hogy a résztvevők ezekből az intézményekből kevésbé elfogadóak a CIES legtöbb (ha nem is mindegyik) állításával, a feltételezett lehetőségekkel kapcsolatban. A vizsgálatba bevont hongkongi hallgatók közül, több szempontot is figyelembe véve, jelentősen kevesebben lettek elfogadóbbak. Ezt a differenciált óravezetés tervezésére rendelkezésre álló idő hiányával, a szükséges szaktudás és készségek hiányával, a munkamennyiség esetleges növekedésével, az osztályokban a tanulmányi eredmények esetleges romlásával, saját munkájuk hatékonyságának esetleges romlásával, a nem fogyatékos tanulók teljesítményének esetleges romlásával és a stresszérzetük növekedésével magyarázták (Sharma et al., 2008).

Összehasonlítva az eredményeket, az tapasztalható, hogy a hong kongi és szingapúri pedagógushallgatók sokkal nagyobb mértékben éreznek aggodalmat, mint a többi országban tanulók. A magyarázat az lehet, hogy ezekben a régiókban bármilyen, az inklúziót támogató jelentős irányelv hiányzik, míg Kanada és Ausztrália oktatáspolitikája határozottan támogatja és segíti az együttnevelést.

De vajon ugyanez megmagyarázhatja-e az öt intézményben a tanárjelöltek hozzáállásában bekövetkezett változásokat is? A válasz erre a kérdésre, legalábbis az ausztráliai és kanadai hallgatók között, igenlő. Az ausztrál és a kanadai tanárképzésben nagy hangsúlyt helyeznek arra, hogy bemutassák a helyi törvényhozásnak azokat a részeit, amelyek kapcsolatban vannak a fogyatékosokkal és az együttneve- 
léssel. Ezen programoknak köszönhetően a diákok megismerik azokat az önkormányzati erőforrásokat is, amelyekkel az önkormányzat az inkluzív oktatást támogatja, ami enyhíti a pedagógusjelöltek együttnevelés miatti aggodalmait. Ráadásul ugyanilyen hangsúlyt kapnak a képzésben a gyakorlati stratégiák is (például differenciált óravezetés, kooperatív tanulás, tanulópárok), amelyek szintén hozzájárulhatnak ahhoz, hogy jelentősen csökkentsék a résztvevők aggályait.

A félelmek legjelentősebb enyhülése az ausztrál hallgatók körében volt tapasztalható. Ez azzal magyarázható, hogy megfelelő feladatokat kaptak. Az egyik ausztrál intézményben a pedagógusjelöltektől azt kérték, hogy fogalmazzanak meg legalább egy aggodalmat az inkluzív oktatással és stratégiákkal kapcsolatban, hogy a kurzus alatt érinthessék és feldolgozhassák ezeket. A másik kérés pedig az volt, hogy folyamatosan jelezzék a kérdéseiket, aggodalmaikat a szemeszter alatt (három hónap). A szemeszter során a hallgatóknak módjuk volt sok „eredeti” tevékenység vállalására és elvégzésére (például a tárgyhoz tartozó kutatás, tanulmányok, cikkek és dokumentum olvasása, tanulmányi tervek készítése és implementációja). A célzott feladatok eredményeképpen a diákok egyre megfontoltabban fogalmazták meg az aggályaikat (Sharma et al., 2008).

Ha napjaink jövőbe tekintő pedagógusképzése azt tűzi ki célul, hogy felkészítse a pedagógusjelölteket az inkluzív osztálytermi munkára, hogy a jelöltekkel megismertesse és elfogadtassa az inklúzió filozófiáját, szükséges, hogy a hallgatók elég tapasztalatot szerezzenek ahhoz, hogy ne érezzék kényelmetlenül magukat, ha kapcsolatba kerülnek sérült emberekkel. Fontos továbbá, hogy a tanárjelölteknek legyen lehetőségük minél több alkalommal, helyzetben és módon megfogalmazni aggodalmaikat azzal kapcsolatban, hogy inkluzív osztályban, iskolában kell majd a jövőben dolgozniuk. Ha a tanárképzési programok figyelmet szentelnek az oktatáspolitika által is támogatott együttnevelésre, a tanárképzőknek mindenképpen szükséges tudniuk azt, hogy milyen pedagógusképzés képes jól képzett és a feladat felé pozitívan forduló pedagógusokat szárnyra bocsátani.

A különböző típusú programokkal dolgozó pedagógusképző intézmények különbözőségük ellenére is hasonló pozitív változást eredményez(het)nek a hallgatók hozzáállásában. A jelen tanulmány alapjául szolgáló kutatási adatok (Forlin et al., 2007), összefoglalásaként megállapítható, hogy mind a diffúz modell, mind az önálló tantárgyi modellek egyaránt hatásosak lehetnek, s hogy egy tanárképzési program filozófiája és tartalma jó elörejelzője lehet a jövendő pedagógusok inklúzióval kapcsolatos hozzáállásának, véleményeinek és aggodalmainak. Azok a pedagógushallgatók, akik közvetlen és közvetett módon rendszeresen kapcsolatba kerültek fogyatékos személyekkel, úgy érezték, hogy jobban megértik a fogyatékosok életének különböző akadályait, tájékozottabbak a helyi, inklúziót támogató oktatáspolitikában és törvényhozásban, mindez jelentősen hozzájárult az inklúzióval kapcso- 
latos attitüdjeik pozitív változásához. Szükség van további vizsgálatokra, a kutatási eredményeknek és tapasztalatoknak a közzétételére, hogy konkrétabb, célirányosabb kérdéseket tudjunk megfogalmazni, és a kérdésekre pontosabb, általánosíthatóbb válaszokat tudjunk adni. Továbbmenve, olyan kutatásokra és tanulmányokra is szükség van, amelyek vizsgálják a különböző típusú pedagógusképző programok hosszú távú hatékonyságát, az inkluzív neveléssel kapcsolatos attitűdökre, véleményekre és aggodalmakra gyakorolt hatásukat.

Semmiképpen nem tekinthetünk az együttnevelés gyakorlatára úgy, mint egy, csak az SNI tanulók érdekeit szolgáló feladatra és gyakorlatra, hiszen miközben a pedagógusok az osztályban tanuló SNI gyerekekkel foglalkoznak, várhatóan szakmai haszonra tesznek szert, szakmai tudásuk, módszereik, technikájuk gazdagodik és színesedik. Ezért a közeljövő feladata annak hangsúlyozása, hogy az inkluzív nevelés javíthatja a pályán lévő tanárok szakmai perspektíváit. Nem szabad elfeledkezni a fogyatékos gyerekek véleményének kutatásáról sem, hasznos megismerni azt is, hogy az érintett diákoknak mi a véleménye az inklúzióról, milyen érzés számukra inkluzívan nevelkedni.

\section{Irodalom}

Avramidis, E., Bayliss, P., Burden, R. (2000): Student teachers' attitudes towards the inclusion of children with special educational needs in the ordinary school. Teaching and Teacher Education, 16. 277-293.

Avramidis, E., Norwich, B. (2002): Teachers' attitudes towards integration/inclusion: A review of the literature. European Journal of Special Needs Education, 2. 129-147.

Bender, W., Vail, C., Scott, K. (1995): Teachers' attitudes toward increased mainstreaming: Implementing effective instruction for students with learning disabilities. Journal of Learning Disabilities, 2. 87-120.

Bradshaw, L., Mundia, L. (2005): Understanding pre-service teachers' construct of disability: A metacognitive process. Disability \& Society, 5. 563-574.

Center, Y., Ward, J. (1987): Teachers' attitudes towards the integration of disabled children into regular schools. The Exceptional Child, 1. 41-56.

Cook, B. (2002): Inclusive attitudes, strengths, and weaknesses of pre-service general educators enrolled in a curriculum infusion teacher preparation program. Teacher Education and Special Education, 3. 262-277.

Forlin, C. (1995): Educators' beliefs about inclusive practices in Western Australia. British Journal of Special Education, 22. 179-185.

Forlin, C., Douglas, G., Hattie, J. (1996): Inclusive practices: How accepting are teachers? International Journal of Disability Development and Education, 43. 119-133.

Forlin, C. (2001): Inclusion: Identifying potential stressors for regular class teachers. $E d u$ cational Research, 3. 235-245.

Forlin, C. (2003): Pre-service teacher education: Involvement of students with intellectual disabilities. International Journal of Learning, 10. 183-200. 
Forlin, C., Fogarty, G., Carroll, A. (1999): Validation of the factor structure of the interactions with disabled person's scale. Australian Journal of Psychology, 51. 50-55.

Forlin, C., Loreman, T., Sharma, U., Earle, C. (2007): Demographic differences in changing preservice teachers' attitudes, sentiments and concerns about inclusive education. International Journal of Inclusive Education, 2. 150-159.

Forlin, C., Sin, K. (2010): Developing support for inclusion: a professional learning approach for teachers in Hong Kong. International Journal of Whole Schooling. URL: http://www.thefreelibrary.com/Developing+support+for+inclusion $\% 3 \mathrm{a}+\mathrm{a}+$ professiona 1+learning+approach...-a0218657711

Hastings, R., Graham, S. (1995): Adolescents' perceptions of young people with severe learning difficulties: The effects of integration schemes and frequency of contact. Educational Psychology, 15. 149-159.

Hastings, R., Oakford, S. (2003): Student teachers' attitudes towards the inclusion of children with special needs. Educational Psychology, 1. 87-94.

Hodge, S., Jansma, P. (1999): Effects of contact time location of practicum experiences on attitudes of physical education majors. Adapted Physical Activity Quarterly, 16. 48-63.

Kowalski, E. (1995): The infusion approach to teacher development. Journal of Physical Education, Recreation, and Dance, 4. 49-54.

Loreman, T., Earle, C. (2007). The development of attitudes, sentiments, and concerns about inclusive education in a content-infused Canadian teacher preparation program. Exceptionality Education Canada, 1. 85-106.

Norwicki, E., Sandieson, R. (2002): A meta-analysis of school age children's attitudes toward persons physical or intellectual disabilities. International Journal of Disability, Development and Education, 3. 243-265.

Sharma, U., Desai, I. (2002): Measuring concerns about integrated education in India. The Asia-Pacific Journal on Disabilities, 1. 2-14.

Sharma, U., Earle, C., Desai, I. (2003): A comparison of Australian and Singaporean preservice teachers' attitudes and concerns about inclusive education. Teaching and Learning, 2. 207-217.

Sharma, U., Forlin, C., Loreman, T., Earle, C. (2006): Pre-service teachers' attitudes, concerns and sentiments about inclusive education: An international comparison of the novice pre-service teacher. International Journal of Special Education, 2. 80-93.

Sharma, U., Forlin C., Loreman, T. (2008): Impact of training on pre-service teachers' attitudes and concerns about inclusive education and sentiments about persons with disabilities. Disability \& Society, 7. 773-785.

Subban, P., Sharma, U. (2005): Understanding educator attitudes toward the implementation of inclusive education. Disability Studies Quarterly, 2. URL: http://www.dsq-sds.org.

Wilczenski, F. (1992): Measuring attitudes toward inclusive education. Psychology in the Schools, 29. 306-312.

Wilczenski, F. (2005): Development of a scale to measure attitudes toward inclusive education. Educational and Psychological Measurement, 55. 291-299. 